\title{
Weakness of Will : Reformation Anthropology between Aristotle and the Stoa
}

\section{Saarinen, Risto Juhani}

Vandenhoeck \& Ruprecht

2015

Saarinen, R J 2015, Weakness of Will : Reformation Anthropology between Aristotle and the Stoa . in A Eusterschulte \& H Wälzholz (eds), Anthropological Reformations -

Anthropology in the Era of Reformation . Refo500 academic studies, vol. 28 , Vandenhoeck \& Ruprecht, Göttingen , pp. 17-33 .

http://hdl.handle.net/10138/302097

acceptedVersion

Downloaded from Helda, University of Helsinki institutional repository.

This is an electronic reprint of the original article.

This reprint may differ from the original in pagination and typographic detail.

Please cite the original version. 
Weakness of Will: Reformation Anthropology between Aristotle and the Stoa

Risto Saarinen

The so-called weakness of will, sometimes called with the Greek term akrasia or the Latin term incontinentia, belongs to those perennial topics of Western philosophy that each new generation wants to elaborate and discuss. Akrasia means acting against better judgment, that is, the situation in which one knows what good one ought to do but nevertheless does something else. ${ }^{1}$

The theme of akrasia is usually considered to have its origins in Aristotle's Nicomachean Ethics, (EN, Book VII), in which Aristotle discusses the phenomenon of acting against one's own better judgment. Since knowledge is stronger than opinions or emotions, and since better judgments represent this knowledge, no rational person should act against what he or she considers best. Aristotle is, however, not only intellectualist but also realist; therefore, he remarks that often people nevertheless seem to act akratically. How can this phenomenon be explained? Aristotle presents a lengthy elaboration and explanation. Later philosophers and theologians have debated what Aristotle is actually saying and whether he is right in saying what he says. ${ }^{2}$

\section{Akrasia in Aristotle and the Stoa}

As one crucial part of his explanation, Aristotle launches the practical syllogism, a calculative model of the emergence of human action. The practical syllogism consists of a major premise that expresses a general principle and a minor premise that states a particular observation. Given the intellectualist framework, rational beings should follow the conclusion implied by the two premises. Aristotle's famous example in EN VII concerns eating: "Sweet things are to be avoided" (major); "this is sweet" (minor); "this should be avoided" (conclusion). The conclusion is not only propositional, but also functional and in some sense the action itself. Hence, a person's acts result from his or her calculative deliberations in terms of practical syllogism. (EN VII, 1145a-1147b).

The standard Aristotelian answer to the problem of akrasia is that the akratic person knows the good in a universal sense but his grasp of the minor premise is impeded or imperfect. Thus, the akratic person eats the sweets, knowing that sweet things should generally be avoided, but cheating himself to ignore the particular case at hand. (EN VII, $1147 \mathrm{a}-\mathrm{b})$. Obviously, the next thing to ask is whether the ignorance in question is voluntary or not. A great range of different answers has been presented, and sometimes the same author has presented many answers. Thomas Aquinas, for instance, says that philosophically such behavior is like involuntary forgetting, but theologically it is voluntary. ${ }^{3}$

${ }^{1}$ TOBIAS HOFFMANN (ed.) Weakness of Will from Plato to the Present, Washington 2008. JÖRN MÜLLER, Willensschwäche in Antike und Mittelalter, Leuven 2009. RISTO SAARINEN, Weakness of Will in Renaissance and Reformation Thought, Oxford, 2011.

${ }^{2}$ MÜlLER, Willensschwäche (see n. 1), pp. 109-151; SAARINEN, Weakness (see n. 1), pp. 8-12.

${ }^{3}$ So SAARINEN, Weakness (see n. 1), pp. 28-30. More discussion about Aquinas is listed here. 
In addition to Aristotle, there is a Stoic tradition of akrasia of which the scholars have become better aware during the last fifteen years. ${ }^{4}$ The Stoic tradition is quite fragmentary; we have some texts of Chrysippus and Galen, and uncertain mentions from Plutarch, Epictetus and Origen. I am also arguing in my new book that Augustine is in some ways connected to this tradition. ${ }^{5}$

The Stoic tradition survives in some examples, of which the two most popular are, first, "the runner who cannot stop running" and, second, the literary figure of Medea who falls in love and kills her children against her better judgment. Both Medea's love and her rage are used as example of akrasia. The Stoics introduced the concept of assent to their anthropology. This assent was no free will in the modern sense, but something that is immediately attached to the judgment of the mind. According to the Stoics, our emotions are assented judgments. When we feel an emotion, we have already judged to assent it. Emotions are no innocent desires but assented judgments. Thus the Stoics are in some sense even more intellectualist that the Aristotelians who taught that the emotions stem from the lower parts of the soul, being in themselves no rational judgment or voluntary consent of higher mental powers. ${ }^{6}$

As strict intellectualists, the Stoics are unwilling to admit that there exists something like akrasia. Motivational mental conflicts only mean that the assented judgment oscillates and changes in both directions so rapidly that we cannot notice the individual instances of this rapid change. However, in each individual instance of this very rapid oscillation there is a coherence of assent, judgment and the emotion representing them. ${ }^{7}$

However, the Stoics discuss two possible options of akrasia. First, there may be so-called prepassions, which emerge already before judgment. If I see a box of sweets in the shop window, this impression may cause tiny physical changes within me before the judgment, assent and emotion are fully formed in the soul. Such tiny changes could be labeled as akratic, and we may have them for a very brief time before the conscious judgment emerges. Although the doctrine of prepassions became prominent in later Christian monastic spirituality, the other option is more interesting for the purposes of this paper. In some cases, the agent may be so strongly predetermined by some earlier habits that the new information cannot change his or her course of action immediately but only after delay. This is what the example of the "runner who cannot stop running" illustrates. After the assented judgment to stop running, the runner proceeds at least for some meters. This proceeding might be called akrasia, acting against one's own better judgment. ${ }^{8}$

This was also how Medea's love and her rage came to be interpreted. In Ovid's Metamorphoses Medea claims to "see the better and approve it, but follow the worse". This means, according to the Stoic view, that she saw that it was better to stay at her father's home, but her love nevertheless caused her to continue with Jason. Although she intellectually decided to stay with her father, her earlier course of life was still so predominant that in her love she actually followed Jason. ${ }^{9}$

\footnotetext{
${ }^{4}$ MÜLLER, Willensschwäche (see n. 1), pp. 155-193 offers a broad overview.

${ }^{5}$ SAARINEN, Weakness (see n. 1), pp. 19-27.

${ }^{6}$ SAARINEN, Weakness (see n. 1), pp. 12-17.

${ }^{7}$ SAARINEN, Weakness (see n. 1), p. 15 and MÜLLER, Willensschwäche (see n. 1), p.

${ }^{8}$ SAARINEN, Weakness (see n. 1), p. 16 and MÜLLER, Willensschwäche (see n. 1), pp.
} 167-171. 171-179.

${ }^{9}$ SAARINEN, Weakness (see n. 1), pp. 16-17; MÜLLER, Willensschwäche (see n. 1), 
Jörn Müller has meticulously analyzed the Stoic tradition of akrasia; he also discusses its relationship to some early Christian mental conflicts, for instance, Paul's introspection in Romans 7. In my own book, I present two new arguments concerning Augustine's very complex role in this story. First, I claim that Augustine's famous conversion story in Confessions 8 displays similarities with the example of the "runner who cannot stop running". Here Augustine wonders why the commandment of the mind to will does not bring about a will-act, calling this powerless will a monstrosity. He explains the phenomenon by saying that, though the mind is lifted up by truth, it is also weighed down heavily by habit, and it is this old habit which causes the person to act against his better will and judgment. ${ }^{10}$

Second, I interpret the late Augustine's pessimistic lines of the remaining sinfulness of Christians as saying that Augustine there regards concupiscence not only as irrational emotion but also in terms of an assented judgment. Because we feel concupiscence, we have somehow already assented to it; therefore, the awareness of one's feeling concupiscence is already in itself sinful, involving preceding consent in some sense. In fact, the case of Augustine is very complex. His doctrine of desire, consent and free will cannot be reduced to Stoicism but it also exemplifies new developments. At the same time, the notion of consent/assent stems from Stoicism and we may ask to what extent this shapes Augustine's thinking. Timo Nisula discusses Augustine in detail, without fully agreeing with my views regarding his Stoicism. ${ }^{11}$ For my purposes, it is sufficient to show that Augustine can be read in somewhat Stoic terms. This is relevant in the reception history irrespectively of whether this was the case with the historical Augustine.

\section{Other Introductory Perspectives}

Some introductory perspectives need to be stated clearly, before I can enter the topic.

First, it is evident that since Melanchthon the Reformation authors knew much more about Stoicism than was the case in late medieval scholasticism. Several Reformation authors knew well the non-religious Greek sources and could thus compare their theology competently with the classical heritage. Thus, we have not only Aristotelianism but also a kind of Neo-Stoicism as an available option in the Reformation era.

Second, I will not claim that the Reformation authors were either Aristotelians or Stoics. They differed from both in many important respects. However, some of them are Aristotelian in their explanation of akrasia, whereas others employ distinctly Neo-Stoic features. While they all remain somewhere between Aristotle and the Stoa, it is worthwhile to discover the individual affinities and differences.

Third, to verify such discoveries we need a clear framework of relevant comparisons. For this purpose, I will employ a categorization of the different models of akrasia as being either Aristotelian or Stoic. The use of practical syllogism as explanatory model is typical of Aristotelianism. Within this model, one may have slightly different explanations as to how the syllogism can go wrong, but I will not address them in the following. The Stoic models are characterized by the use of the concepts of assent/ consent/ free will. They proceed from

pp.173-176.

${ }^{10}$ MÜLLER, Willensschwäche (see n. 1), pp.211-241 (Paul); SAARINEN, Weakness (see n. 1), pp. 17-26 (Augustine).

${ }^{11}$ TIMO NisUlA, Augustine and the Functions of Concupiscence, Leiden, esp. pp. 259-262. 
strictly Stoic intellectualism towards Augustinianism, and further from Augustinianism towards voluntarism. While the full-fledged free will models are no longer Stoic, the Augustinian models that employ the interplay of desire and consent still display some Stoic features. ${ }^{12}$

Fourth, the role of Martin Luther in this history needs to be explained. In some sense, he does not belong to it, since he did not write anything on akrasia. In my new book, I ask the inevitable question: why not, given that he knew Aristotle well and was so interested in the so-called bondage of the will. My answer is that, for Luther, akrasia was not a conceptual option in the first place. ${ }^{13}$ Why is this so? For Aristotle, akrasia and enkrateia, the strength of will, are imperfect stages of virtue and vice. Imperfectly good people act virtuously but have temptations to do otherwise. They are called enkratic or (in Latin) continent. Imperfectly evil people commit sins but they act against their better judgment, being akratic. In Aristotle, we thus have four moral states, virtue, continence, akrasia, and vice.

For Luther, however, all people without grace are wholeheartedly evil and sinful; there are no alleviating factors. For this reason, people who claim to be akratic are just normally evil and maybe hypocrites. When people are justified and live a Christian life, they act rightly but their ruled sin nevertheless tempts them all the time. They are righteous and sinner at the same time. In Aristotelian terms, they are continent rather than virtuous. If Christians lapse from the good course of life, they re-enter the state of normal sinners. When they return to the path of faith and Christianity, they become righteous sinners or continent in Aristotelian terms. Only in heaven can they become really good and virtuous. The four Aristotelian moral states are thus reduced to two in Luther, namely, vice and continence. Given this, Luther need not write anything concerning people who without grace nevertheless have good judgment: there are no such people.

\section{Early Lutheranism}

We can also bluntly say that Luther kicked Aristotle out of the door. The philosopher starts to creep back from one window opened by Melanchthon and another opened by Calvin. Melanchthon does not write much thematically on akrasia. For the most part, he shares Luther's view that only sinfulness and continence are the real Christian options.

Melanchthon's portrayal of the human will is Lutheran rather than Erasmian or Humanist. ${ }^{14}$

In the second aetas of the Loci communes, however, Melanchthon undertakes some moderations to Luther's teaching concerning the natural powers of humanity without grace. He considers that people can have a remnant of judgment with which they can proceed to externally good works. The weakness of our nature frequently overcomes any good judgment, so that we follow evil affects. Medea's words: I see the better and approve it, but follow the worse, exemplify this situation. ${ }^{15}$

${ }^{12}$ A detailed categorization is presented in SAARINEN, Weakness (see n. 1), pp. 42, 217.

${ }^{13}$ See SAARINEN, Weakness (see n. 1), pp. 115-132.

${ }^{14}$ So TIMOTHY Wengert, Human Freedom, Christian Righteousness, Oxford 1998.

${ }^{15}$ Melanchthon, Corpus Reformatorum (CR, Halle, 1834-1860) v. 21, p. 374: "Hanc ipsam libertatem efficiendae civilis iustitiae saepe vinci naturali imbecillitate, saepe impediri a Diabolo. Nam cum natura sit plena malorum affectuum, saepe obtemperant homines pravis cupiditatibus, non recto iudicio. Sicut inquit apud Poetam Medea: Video 
Medea's words are not used in medieval theology and philosophy, but they are reintroduced by Josse Clichtove in his influential ethics textbook around 1500 as illustration of akrasia. After Clichtove and Melanchthon, they are used by practically all later writers. ${ }^{16}$ More importantly, they were used as an example of weakness of will, not as any example whatsoever. Melanchthon is very fond of Medea's example; he interprets Medea's love and her rage in several different works throughout his later career as Reformer. ${ }^{17}$ Let us keep in mind that Medea's words are non-Aristotelian: if Medea really saw the better, without any ignorance or forgetting, she, according to Aristotle's intellectualist theory, should have followed this course. Medea exemplifies something that is called clear-eyed akrasia in philosophical literature.

We know today how the example of Medea was employed in the Stoic discussion on akrasia. ${ }^{18}$ Therefore, we need to ask whether the reintroduction of this example by Clichtove and Melanchthon implies the reintroduction of Stoicism into the discussion on weakness of will. Several qualifications are here needed, as Medea's example can be understood as being simply voluntarist. In some respects, Melanchthon's interpretation resembles Aristotelianism: the akratic Medea ignores the good judgment at the very moment of her sinful action. Melanchthon sometimes says that the devil causes this ignorance of particulars. ${ }^{19}$

On the other hand, Melanchthon knew the Greek sources so well that he probably realized that the example of Medea manifests Stoic rather than Aristotelian action theory. The frequent use of this example turns, I think, his action theory to some extent towards the Stoa. Melanchthon's significance in the interpretation history of akrasia lies, however, primarily in his ability to reconnect the classical discussion with the emerging Lutheran theology. His use of the relevant examples is eclectic and rhetorical rather than fully consistent.

The first Lutheran to develop a sophisticated, original and highly tradition-conscious notion of akrasia is Melanchthon's pupil Joachim Camerarius. He is clearly a major figure not only in Lutheranism, but also in the entire interpretation history of akrasia in Western philosophy. His insights radiate far and deep, up to such founding fathers of modernity as Spinoza and Leibniz. ${ }^{20}$ Here I can only very briefly sketch some basic features of Camerarius's Exposition of Nicomachean Ethics.

Camerarius knows well the Platonic and Stoic traditions, but he adheres to Aristotelianism, which he attempts to harmonize with Melanchthon's theological and philosophical insights. He keeps the structure of the practical syllogism and argues, in keeping with the Aristotelian tradition, that the particular facts of the minor premise are not grasped properly in the akratic deliberation. Thus, some ignorance precedes akratic acts.

meliora proboque, deteriora sequor. Praeterea Diabolus captivam naturam impellit ad varia flagitia etiam externa, sicut videmus summos viros, qui tamen conati sunt honeste vivere, lapsus turpissimos habere. Sed tamen inter has difficultates, utcunque reliqua est aliqua libertas efficiendae iustitiae civilis."

${ }^{16}$ SAARINEN, Weakness (see n. 1), pp. 79-83 (Clichtove).

${ }^{17}$ SAARINEN, Weakness (see n. 1), pp. 132-142.

${ }^{18}$ MÜLLER, Willensschwäche (see n. 1), pp. 165-179.

${ }^{19}$ See above n. 15.

${ }^{20}$ SAARINEN, Weakness (see n. 1), pp. 142-151 (Camerarius), pp. 225-229 (Spinoza, Leibniz). 
Unlike the former Aristotelians, however, Camerarius considers that the uncertainty related to our perception of empirical particular is nothing less than "the cause of all evil". ${ }^{21}$

He gives three new and non-Aristotelian examples of akrasia, which signify this circumstance in a very broad manner. A medical doctor knows well the general regularities regarding how to treat fever. However, it is very difficult to know which general principle applies to this particular case of fever. Therefore, he often fails to heal, as the medical knowledge concerning particulars is not certain. The second example concerns political leadership, in which even wise men often fail for the same reason: they know the general rules, but they cannot foresee whether they work properly in this particular case. A third example concerns the composition of literary texts: even very skillful authors make all kinds of blunders, as the procedure from general stylistic and rhetorical rules to concrete cases of writing convincingly is so hard to accomplish. ${ }^{22}$

The error of the akratic person thus concerns the particular circumstances: the devil is in the details. In some sense, this is close to the Aristotelian syllogistic model, but Camerarius is so focused on the uncertainty of particulars that we cannot call him Aristotelian. ${ }^{23}$ The neglect of the particulars is also voluntary, as the following quote shows:

The [akratic] argument goes as follows: this desire is harmful. Harmful things are to be avoided. Therefore, one should not be seized by this desire. But covetousness carries the person away, so that he is ordered by this last proposition concerning perception: this is pleasant and joyful. Therefore, I enjoy the present pleasure. The person does not want to hear or follow the knowledge-based truth, which argues that such deeds are wicked and blameworthy. In the same manner, one can explain other cases in which one acts against true knowledge and right reason. ${ }^{24}$

These considerations of Camerarius advance significantly from the schematic treatments of Luther and Melanchthon. At the same time, they differ from the earlier Aristotelian tradition. The weight of empirical particulars and the uneasiness provided by small changes is something that we encounter later in Leibniz, for instance, but it is not a main theme before Camerarius. Because of the voluntary nature of the neglect of details, Camerarius is closer to late medieval voluntarism than to either Aristotle or the Stoa. It is worthwhile to note that while Luther denies akrasia completely and Melanchthon offers it a minor role in our external behavior, Camerarius makes akrasia the cause of all evil. The topic that has no conceptual place in Luther thus soon becomes prominent in Lutheranism and receives new significance as a ground of empirical observation.

After Camerarius, Lutherans start to write extensively on akrasia. They often return to the Aristotelian and even Thomistic doctrines and do not display much originality. They aim to make Aristotelianism compatible with the theological doctrines of the Reformation, sometimes even managing to do some creative work towards this goal. Theophilus Golius of Strasbourg and Wolfgang Heider of Jena can be mentioned as examples of this development.

\section{${ }^{21}$ JOACHIM CAMERARIUS, Explicatio librorum Ethicorum ad Nicomachum,} Frankfurt, 1578, p. 325. SAARINEN, Weakness (see n. 1), pp. 147-148.

${ }^{22}$ CAMERARIUS, Explicatio (see n. 21), pp. 325-326; SAARINEN, Weakness (see n. 1), p. 148.

${ }^{23}$ CAMERARIUS, Explicatio (see n. 21), p. 326; SAARINEN, Weakness (see n. 1), p. 148.

${ }^{24}$ CAMERARIUS, Explicatio (see n. 21), p. 326; SAARINEN, Weakness (see n. 1), pp. 149-150. 
They return to the Aristotelian anthropology, although they continue to use the example of Medea and stress the sinful nature of all human beings. In reality, however, their Aristotelian anthropology is clearly distinct from Luther's reductionist doctrine of all humans being either wicked or enkratic. ${ }^{25}$

\section{Early Calvinism}

The Calvinist interpretation history of weakness of will is fascinating for many reasons. First, Calvin himself launches this history through discussing akrasia already in the 1539 edition of his Institutio. Second, Lambert Daneau undertakes an original systematic interpretation of akrasia and enkrateia in his Ethices Christianae. Third, the Neo-Stoic influence on this discussion seems to be stronger in Calvinism than in the Catholic and Lutheran interpretation history.

Calvin's treatment shows familiarity with the basic Reformation ideas of Luther and Melanchthon. Calvin discusses akrasia in the context of the so-called theological use of the law. This use brings the knowledge of sin. He emphasizes the role of conscience as an instance that exercises some influence even in corrupted human minds. Calvin concludes therefore, in keeping with Melanchthon, that although sinners try to evade their inner power of judgment, the mind at least sometimes opens itself to the judgment of conscience. This means that we do not only sin from ignorance and that genuine acting against better judgment is possible because of the remaining power of conscience to produce such jugdments. ${ }^{26}$

This leads Calvin to present an Aristotelian solution to the problem of akrasia in terms of practical syllogism. Although he attributes this model to Aristotle's pupil Themistius, it can be found in the standard Aristotelian commentaries, for instance, in Thomas Aquinas or Calvin's contemporary John Mair. ${ }^{27}$ Calvin says:

Themistius more correctly teaches that the intellect is very rarely deceived in general definition or in the essence of the thing; but that it is illusory when it goes farther, that is, applies the principle to particular cases. In reply to the general question, every man will affirm that murder is evil. But he who is plotting the death of an enemy contemplates murder as something good. The adulterer will condemn adultery in general, but will privately flatter himself in his own adultery. Herein is man's ignorance: when he comes to a particular case, he forgets the general principle that he has just laid down. ${ }^{28}$

In this manner, the conscience illuminates the major premises but not the minor ones and the $\sin$ is indeed to some extent due to ignorance. However, Calvin adds another perspective to this discussion as follows:

Themistius' rule, however, is not without exception. Sometimes the shamefulness of evil-doing presses upon the conscience so that one, imposing upon himself no false image of the good, knowingly and willingly rushes headlong into wickedness. Out of such a disposition of mind come statements like this: 'I see what is better and approve

${ }^{25}$ SAARINEN, Weakness (see n. 1), pp. 151-163 (Golius and Heider).

${ }^{26}$ Institutio christianae religionis, 2, 2, 22. The following English quotes are from Institutes of the Christian Religion (ICR, Louisville, 2006). In SAARINEN, Weakness (see n. 1), pp. 164-174 I pay detailed attention to the different editions of Institutio.

${ }^{27}$ For Mair, see SAARINEN, Weakness (see n. 1), pp. 83-95.

${ }^{28}$ Inst. 2, 2, 23 (ICR, p. 282). 
it, but I follow the worse.' To my mind Aristotle has made a very keen distinction between incontinence and intemperance: where incontinence reigns, he says, the disturbed mental state or passion so deprives the mind of particular knowledge that it cannot mark the evil in its own misdeed, which it generally discerns in like instances; when the perturbation subsides, repentance straightway returns. Intemperance, however, is not extinguished or shattered by the awareness of sin, but on the contrary, stubbornly persists in choosing its habitual evil. ${ }^{29}$

Calvin now employs the favorite example of Melanchthon, namely, Medea's love. As clear-eyed wrongdoing, Medea is for Calvin not a case of akrasia but of intemperance, which in the Aristotelian scale is a standard vice. The passage is somewhat idiosyncratic or at least non-Aristotelian, as for Aristotle, people performing such wrongdoing are not conscious of the better alternative but their mind is entirely fixed on wrongdoing. For our interpretation history it is nevertheless significant that the topic of akrasia is discussed by Calvin and that the attempts to keep both the Aristotelian practical syllogism and the non-Aristotelian example of Medea. His strong doctrine of conscience comes to some extent from Luther and Melanchthon. Interestingly, also some Catholic authors, for instance, John Mair, employ a strong concept of conscience in their discussion of akrasia. ${ }^{30}$

Among the early Calvinist authors on akrasia, Lambert Daneau is particularly interesting for several reasons. He is often considered the first author who launches a Christian ethics, understanding ethics no longer as a philosophical but a theological discipline. At the same time, he continues both the Aristotelian and the Stoic traditions, as Christoph Strohm's study shows in great detail. ${ }^{31}$ There is yet another reason why Daneau is particularly significant. Daneau is the first author who takes very seriously Martin Luther's view of the Christian as "righteous and sinner at the same time" and consistently applies it to ethics. While Melanchthon and Calvin also take over this idea from Luther, they do not work it out in detail and do not fully grasp its significance for the analysis of the human condition. The Reformation anthropology that has its origins in Luther receives its first fully elaborated moral-philosophical expression in Daneau's Christian ethics.

Let me explain briefly what I mean by this claim. Daneau makes a distinction between philosophical and Christian ethics. He says that philosophical ethics cannot understand the struggle between reason and the appetitive powers properly. Philosophers claim that this struggle can be successfully mastered through the repeated practice of good actions, but they do not grasp the real cause o appetitive powers, that is, sin. Their view also wrongly ascribes the merit of good actions to people, not to God. Only Christian ethics can see that people without God cannot do any good. When God's spirit has renewed them, they can cooperate with the Spirit. Even then, humans cannot achieve a perfect virtue in this life. Their Christian virtue remains an enkratic/continent state in which the subjects are not in autonomous control of their actions. ${ }^{32}$

When Daneau launches his doctrine of perfect and imperfect virtue, he deviates from the Aristotelian tradition already in the number of pages devoted to both. While virtue is defined in seven pages, the definition of imperfect virtue, that is, of continence and akrasia, takes

\footnotetext{
${ }^{29}$ Inst. 2, 2, 23 (ICR, p. 282). SAARINEN, Weakness (see n. 1), p. 166.

${ }^{30}$ So SAARINEN, Weakness (see n. 1), p. 86.

${ }^{31}$ CHRISTOPH STROHM, Ethik im frühen Calvinismus, Berlin, 1996.

${ }^{32}$ SAARINEN, Weakness (see n. 1), pp. 188-200.
} 
eighteen pages. ${ }^{33}$ Moreover, Daneau undertakes this division with a reference to Stoicism: he says that the Stoics teach that the wise can operate at the stage of perfect virtue or duty, whereas common people practice the middle level of imperfect virtue. A fully virtuous person has extinguished all affects which go contrary to the Holy Spirit, but in the common people the harmful passions still struggle against virtue. The virtue of such a person can be characterized as wrestling and struggle. ${ }^{34}$ While Daneau consciously thinks about Stoicism, we must also keep in mind that the distinction between the moral states of virtue and continence comes from Aristotle.

Already Melanchthon uses the picture of wrestling to illustrate the Christian existence and the struggle of people like Medea. But Daneau establishes this picture to become a core doctrine of ethics: Christian ethics is concerned with virtus luctans, the virtue which continuously wrestles with harmful affects. The results of this struggle manifest themselves as continence and, in case of failure, as akrasia. Through various references to church fathers, especially Augustine, Daneau points out that no human being can achieve true virtue in this life because the power and tinder of sin are active in us. Even the apostle Paul could not achieve perfect virtue, as Romans 7 shows. Romans 7 is an example of Paul's continence, not of his virtue nor of his weakness of will. This was, by the way, the standard exegetical view shared also by Luther. ${ }^{35}$

This means for Daneau that continence is the best stage that Christians can achieve in this life. It further means that a textbook on Christian ethics has to focus on the so-called wrestling virtue, as it is the option which we really encounter. In this sense Daneau systematizes Luther's view of simul iustus et peccator: he takes seriously the remaining sinfulness and claims therefore that full virtue is not the concrete option in ethics, but rather the wrestling virtue to achieve strength of will, or continence. And even this imperfect virtue is a Christian and not a philosophical virtue. ${ }^{36}$ It is a virtue that acts in cooperation with the Holy Spirit.

Concerning akrasia, weakness of will, Daneau differs from Luther insofar as he admits it as a distinct possibility. He says, for instance, that when the bad will of the mind overcomes the virtue and the desire to act rightly, this state is called akrateia. In this state virtue, fights and struggles with vice, and vice with virtue. We then clearly perceive as if two persons and two wills were active in us. $^{37}$

He also uses the example of Medea as an illustration of akrasia as follows:

When the virtue and the holy desire to do good, which the Spirit of God gives, prevail in this wrestling, the will remaining repugnant, it is called continence. Such is the case of Jacob wrestling with the angel. But when our harmful desire overcomes reason, it

${ }^{33}$ LAMBERT DANEAU, Ethices Christianae libri tres (Geneva, 1583), Book 1, chs. 22 23. SAARINEN, Weakness (see n. 1), p. 190.

${ }^{34}$ DANEAU, Ethices (see n. 33), pp. 99v-100r.

${ }^{35}$ DANEAU, Ethices (see n. 33), p. 101r. I discuss the various stages of the reception history of Romans 7 in SAARINEN, Weakness (see n. 1).

${ }^{36}$ DANEAU, Ethices (see n. 33), p. 107r: "Ergo non animus hominis per se, sed animus hominis iam renovatus huius gradus virtutis, quem Continentiam et Luctam appellamus, quique solus in nobis hic degentibus esse potest, est capax, illiusque sedes, et (ut loquuntur in scholis) verum subiectum."

${ }^{37}$ DANEAU, Ethices (see n. 33), p. 104v. 
is called incontinence. Such is the case of Medea in Ovid: "I see the better and approve it, but follow the worse." 38

Although the Holy Spirit will help the believer so that he or she prevails in the wrestling, temporary lapses to akrasia may thus occur.

The picture of akrasia and wrestling virtue is somewhat complicated in Daneau, because he also applies the Calvinist distinction between the elect and the non-elect. The experience of wrestling is basically an experience of the elect, as it shows that the Holy Spirit is operative in the person. Therefore they will also prevail, being enkratic rather than akratic in the long run (although temporary akrasia may occur). The non-elect do not experience a similar wrestling, since they remain merely carnal. However, Daneau shares Calvin's strong notion of natural conscience in the sense that even some non-elect feel the pangs of conscience and attempt therefore to resist evil. Because they are not elect and do not possess the Holy Spirit, their struggle remains akratic:

[These akratic people] have not renounced their sense of conscience. Because they are non-elect, however, they do not possess the renewing Spirit of God, and their conscience wrestles alone, bravely resisting the harmful passions; but their conscience is overcome by the harmful passions. These people can retain their sound mind and produce better fruits more easily [than the vicious] ${ }^{39}$

Some brave heathens may nevertheless look like the continent wrestlers; they possess something like "shadows" of continence. ${ }^{40}$ But in reality they cannot possess this Christian virtue reserved for the elect.

Daneau is highly original in that he works out the Reformation anthropology so that it can be consistently applied to the framework of Aristotelian ethics. Obviously, the discipline of ethics changes dramatically in this application and becomes Christian rather than philosophical ethics. Daneau is one of the major figures of the entire interpretation history of weakness of will, since he is the first author to make enkrateia and akrasia the main topics of ethics in its entirety. The idea that humans are not capable of virtue but only something like the strength of will in cooperation with God becomes a prominent Protestant doctrine. It continues to shape the Protestant mentality until our times. Therefore, Daneau may be regarded a more faithful follower of Luther than the Lutheran ethicists of $16^{\text {th }}$ and $17^{\text {th }}$ century.

How do these results relate to the groundbreaking study of Christoph Strohm? I do not make Daneau as Stoic as Strohm, who mistakenly thinks that the distinction between imperfect and perfect virtue is of Stoic origin. ${ }^{41}$ Although Daneau mentions Stoicism in this context, the distinction itself is formulated in EN VII and discussed in the entire Aristotelian tradition of ethics. I nevertheless agree with Strohm in that the very idea of struggle and wrestling with perturbations contains something which could be labeled Stoarenaissance in a loose sense. Strohm also considers Daneau as very different from Luther, whereas I connect Daneau strongly with Luther's idea of permanent sinfulness. ${ }^{42}$

${ }^{38}$ DANEAU, Ethices (see n. 33), p. 105r. SAARINEN, Weakness (see n. 1), p. 194.

${ }^{39}$ DANEAU, Ethices (see n. 33), p. 105v.

${ }^{40}$ DANEAU, Ethices (see n. 33), p. 107r: "Ex quo fit ut in caeteris hominibus, qui hoc Dei beneficio carent, non insit vera continentia, sed verae tantum continentiae et luctae umbra quaedam ..."

${ }^{41}$ STROHM, Ethik (see n. 31), p. 111; SAARINEN, Weakness (see n. 1), p. 199.

${ }^{42}$ SAARINEN, Weakness (see n. 1), pp. 199-200. 
In addition to this, we may ask whether the anti-Aristotelian criticism of virtue ethics in both Luther and Daneau has in itself something that could be labeled as Neo-Stoic. The loose concepts of wrestling and perturbations belong to this intellectual current, but one may ask whether the emerging Protestantism develops something like a concept of emotions as already assented judgments. The Lutheran view that concupiscence is in itself sinful lends some support to this idea, as it contains a view of emotion that is culpable in itself. On the other hand, the Reformers I discuss do not want to be identified as Stoics and their concept of passion and perturbation remains in many ways Aristotelian. The new Reformation anthropology thus remains somewhere between Aristotle and the Stoa.

There are nevertheless some indications that especially the second generation of Calvinists adopts consciously some elements of the Stoic theory of emotions as judgements, without explicitly subscribing to this theory. Lambert Daneau has a fascinating theory of inner mental training in which the person looks at the immediate pleasure and pain he or she feels in the pursuit of virtuous renewal. The mental powers have a unity in which one can train something so that the pain felt first may transform into pleasure. Daneau says, for instance:

The pleasure and pain which we feel in the practice of virtue or vice is strongly indicative of their progress and perfection. Those who enjoy the most in doing good progress the most. Those who rejoice only slightly know that that they have progressed only slightly in the pursuit of virtue and true renewal. Those who enjoy doing evil the most are more gravely incontinent. ${ }^{43}$

This doctrine is so rudimentary that it is difficult to evaluate it in detail. The idea of mentoring oneself seems to ascribe some cognitive content to the very concept of emotion. With the mentored change of this content the emotion itself changes; therefore the emotion can be trained.

There is another early Calvinist who is more Neo-Stoic than Luther or Daneau. This is the Ramist scholar Theodor Zwinger. While he claims to be Aristotelian he also considers that the appetite performs some reasoning. For instance, he can describe the struggle of the akratic mind as follows:

A struggle between reason and appetite emerges, reason concluding one way, appetite another. Both employ a mode of reasoning: reason truthfully, appetite in a false manner. We can understand this when we investigate the matter further. ${ }^{44}$

One could in principle say that Zwinger does not really mean the appetite to perform reasoning or that he is just a bad Aristotelian. However, Zwinger he speaks repeatedly of perturbations as cognitive power. He is a trained physician who defends a unified anthropology of body and soul, for instance in the following:

The affect can move the person forcefully so that the judgment of reason is obscured. This can happen with regard to the anger-related perturbations (emerging from anger), but also with regard to the perturbations related to concupiscence (emerging from venereal appetite). These desires manifestly affect the external body of some people

${ }^{43}$ DANEAU, Ethices (see n. 33), p. 111r. SAARINEN, Weakness (see n. 1), p. 198.

${ }^{44}$ THEODOR ZWINGER, Aristotelis Stagiritae de moribus ad Nicomachum libri decem, tabulis perpetuis, quae Commentarium loce esse quaenant, explicati et illustrati (Basel, 1566), p. 212. SAARINEN, Weakness (see n. 1), pp.178-179. 
(so that one can read their faces like a mirror of the soul). When the inner organs of the mind suffer, the mind itself seems to suffer. ${ }^{45}$

This quote can be read in a Neo-Stoic manner, saying that the mind is one. When a perturbation takes over, it also rules the mind with its cognitive capacities. At least Zwinger deviates from Aristotelianism and takes very seriously the motif of continuous struggle. The picture of struggle and wrestling could be interpreted in terms of Aristotelian or Platonic tradition as a conflict between reason and desire. However, this picture becomes so dominant in early Calvinism that it breaks the context of traditional Aristotelianism.

\section{Some Conclusions}

Given this evidence, we may ask whether we can distinguish the Stoic concept of mental struggle from its Aristotelian and Platonic counterparts. In answering this question, I return to the old example of the runner who cannot stop running. This example is not found in the early modern texts, but it may be argued that the idea of remaining sinfulness and the picture of Medea so frequently employed by the authors are similar to the example of the runner. The decision to stop running or to reach for a better life is already made and it is not forgotten. The body nevertheless follows its old course, at least for a while.

For good Lutherans and Calvinists, this "while" lasts the rest of their life; the runner stops running only in the death. The Christian ethics of this life describes the procedure of trying to stop the running, that is, behaving decently in a situation in which the old course still exercises its effects. While I admit that this does not sound quite Stoic, I claim that Luther's simul iustus et peccator and Daneau's Christian ethics contain features that resemble the Stoic example of the runner who cannot stop running. When the Reformers steer their course away from Aristotle, they thus approach the Stoa at least to an extent.

Let me conclude through highlighting some overall developments in the Reformation discussions on weakness of will. Luther denies that carnal people could have a good judgment; he further teaches that all Christians continue to struggle with sin. Akrasia and full virtue are thus no real options. Melanchthon moderates this teaching, allowing some good judgment even in natural reason. However, it is only Camerarius who really launches the discussion on akrasia in Lutheranism. While Luther minimizes akrasia, Camerarius maximizes it, calling it the source of all evil. Camerarius is closer to early modern empiricism than either to Luther or the Aristotelians. After Camerarius, Lutheran ethicists return to the Aristotelian tradition.

The Calvinist Reformation receives Luther more fully on this point than the Lutherans. Calvin himself is close to Melanchthon, the difference being mainly his strong doctrine of innate conscience which makes akrasia a real phenomenon. Lambert Daneau takes over Luther's idea that humans move between vice and continence, wrestling with sin through their entire life. While Luther does not work out the ethical implications of this idea, Daneau does this and develops a full-fledged Christian ethics which has the wrestling virtue of continence as its main feature. For this reason, he is also quite interested in akrasia. Daneau further attaches a strong doctrine of election to his ethical doctrine.

Lutherans threw Aristotle out of the door but he crept back from the window. Before that, however, Lutherans had some brilliant new ideas on akrasia, especially Camerarius who came to be influential until the times of Leibniz. The Calvinists kept Aristotle out more

${ }^{45}$ ZWINGER, De moribus (see n. 44), 211. SAARINEN, Weakness (see n. 1), 177. 
consistently, since they took over the Lutheran idea of permanent sinfulness and made it their core ethical doctrine. The outcome of this process, the new discipline of Christian ethics, or the ethics of wrestling virtue, resembles the old Stoic idea of the runner who cannot stop running. This example was not used in the discussion, but the other prominent example advocating the same idea, that of Medea, was constantly referred to. Obviously, the Christian idea of remaining sinfulness cannot be reduced to Stoicism. Its roots can rather be found in late Augustine. The discussion whether Augustine's view of emotions and human action can be interpreted in a Stoic fashion is thus intimately connected with the issues of Neo-Stoicism in the Reformation. 